\title{
Tecrübeli ve Sinyor Kabin Görevlileri Kapsamında Kabin Ekibi Çatışma Yöntemleri: Bir Havayolunda Kalitatif Araştırma
}

\author{
Teoman ERDAĞ $\breve{G}^{*}$ \\ Murat YAŞLIOĞLU **
}

Öz

\begin{abstract}
Havayolunun karlılık ve sürdürülebilirliği, yolcuları tarafından algılanan hizmet kalitesi düzeyi ile yakından ilişkilidir. Farklı tecrübe ve kıdeme sahip kabin görevlilerinin tutum ve davranışlarının araştırılması ve kabin amirlerinin benimsedikleri çatışma yöntemlerinin belirlenmesi, ekip içi uyumun sağlanarak algılanan hizmet kalitesinin yüksek düzeyde tutulması açısından önem arz etmektedir. Alanyazında, kabin ekipleri tarafından uygulanan çatışma yönetimi yöntemleri hakkında yeterli sayıda çalışma bulunmamaktadır. Araştırma, Türkiye’ de faaliyet gösteren bir havayolunda nitel araştırma yapılarak gerçekleştirilmiştir. Kasti örneklem seçim yöntemi kullanılarak havayolunun en az iki yıllık kabin amirliği tecrübesine sahip kabin amirleri ile yarı yapılandııılmış görüşmeler yapılmıştır. Transfer yoluyla farklı havayollarından gelen tecrübeli kabin görevlileri, tecrübeleriyle ekibe yardımcı olarak hizmet kalitesinin artmasına katkı sağlarken, havayolunun kabin amirliğine terfi edememiş mevcut sinyor (kıdemli) kabin görevlileri ekip uyumunun ve yolcular tarafından algılan hizmet kalitesinin azalmasina neden olabilmektedir. Tecrübeli ve sinyor kabin görevlilerinden yaşça küçük ve daha az tecrübeye sahip kabin amirleri, tecrübeli kabin görevlileri için uzlaşmacı ve sinyor kabin görevlileri için egemen olma çatı̧ma yöntemini benimsemektedir. Kabin ekibi planlama faaliyetlerinde kabin amiri ve kabin görevlilerinin yaş ve deneyimlerinin dikkate alınması, çatışma düzeyinin azaltılarak hizmet kalitesinin artırılmasına katkıda bulunacaktır.
\end{abstract}

Anahtar Kelimeler: Kabin Ekibi, Havayolu, Çatışma Yönetimi

\section{Cabin Crew Conflict within the Scope of Experienced and Senior Cabin Attendants: A Qualitative Research in an Airline}

\begin{abstract}
An airline's profitability and sustainability are closely related to the level of perceived service quality by passengers. Investigating the attitudes and behaviors of cabin attendants with different experience and seniority and determining the conflict methods adopted by cabin chiefs is important in the mean of keeping perceived service quality at a high level by ensuring harmony within the crew. In the literature, there are not enough studies on conflict management applied in cabin crews. Research has carried by using qualitative method in a private airline in Turkey. Semi-structured interviews were conducted with cabin chiefs with at least two years of cabin chief experience by using the deliberate sampling method. Experienced cabin crews, who transferred from different airlines, contribute to the increase of service quality by helping to crew with their experience while senior cabin crews who could not
\end{abstract}

*- Doktora Öğrencisi, İstanbul Üniversitesi, İşletme Fakültesi, İşletme Yönetimi ve Organizasyon, teomanerdag1979@gmail.com, https://orcid.org/0000-0002-3829-7546,

**- Doç. Dr., İstanbul Üniversitesi, İşletme Fakültesi, İşletme Yönetimi ve Organizasyon, murat@yaslıoglu. com, https://orcid.org/0000-0003-2464-5439 


\begin{abstract}
be promoted to the cabin chief position can decrease of crew's harmony and the perceived quality of service. The cabin chiefs, who are younger and less experienced than the experienced and senior cabin attendants, adopt the conflict method of being compromising for experienced cabin attendants and dominating for senior cabin attendants. To contribute to increasing the service quality by reducing the level of conflict, the cabin chief and cabin attendants' age and experiences should take into account in the cabin crew planning activities.
\end{abstract}

Keywords: Cabin Crew, Airline, Conflict Management

\title{
GİRIş
}

Havayolu sektörü, 1903 yılında ilk uçuşun yapılmasından bu yana düzenli olarak büyümekte (Yazgan ve Yiğit, 2013: 421) ve rekabetin şiddeti her geçen gün artmaktadır. Yoğun rekabet ortamında karlılık ve sürdürülebilirliği devam ettirebilmenin yolu, sunulan hizmetin kalitesine ve yolcuların havayolunu tekrar tercih etmesine bağlıdır (Erdağ, 2019:52).

Hizmet kavramı, hizmeti alan ile veren arasında gerçekleşen sübjektif bir olgudur (Assael, 1990: 368). Sunulan hizmetin kalitesinin yüksek olduğu algısının oluşturulması rakiplere karşı rekabet avantajı sağlamaktadır (Yıldız ve Erdil, 2013: 89). Havayolunun görünen yüzü olarak kabul edilen kabin görevlileri, yolcunun algıladığı hizmet kalitesinin belirlenmesinde en önemli paya sahiptir (THK, 2019).

Ekip, belirli bir amaca yönelik olarak bilgi ve tecrübelerini paylaşan üyelerden oluşan grup olarak tanımlanmaktadır (Özdemir, 1999: 17- 24). Ekip olarak üstlenilen görevin başarıyla tamamlanması hem görev paylaşımı hem de ekip çalışması süreçlerini gerektirmektedir. Bireysel görevler, bir ekip üyesinin performansının, diğer ekip üyeleriyle karşılıklı etkileşim gerektirmeyen bileşenleri olarak tanımlanır. Buna karşılık ekip çalışması, birden fazla kişinin performansını etkili bir şekilde koordine etmek için gereken performansın birbirine bağlı bileşenleridir (Mitropoulos ve Memarian, 2012: 1182).

Havayolu sektöründe, diğer birçok sektörde gerçekleştirilen ekip oluşturma uygulamalarından farklı biçimde, düzenli olarak birlikte görev yapan üyeler yerine hemen her uçuşta farklı üyelerden meydana gelen bir ekip oluşturma yöntemi uygulanmaktadır (Akyurt ve Yaşlığlu 2018: 431). Bu durum, büyük olasılıkla daha önce tanışmamış ya da çok az etkileşimde bulunmuş kabin görevlilerinin, bir uçuş görevi için bir araya gelerek önceden belirlenmiş prosedürler ve çalışma talimatlarına göre görev paylaşımı yapmalarına neden olmaktadır (Ku vd., 2014: 119).

Çatışma, çıkarlarda algılanan bir sapma veya tarafların mevcut isteklerinin aynı anda sağlanamayacağına dair bir inancın mevcudiyeti olarak tanımlanmaktadır (Rubin vd., 1994). Günümüzde yönetim uygulamaları, şiddetli rekabet ortamında ve hızla değişen çevre koşullarının etkisi altında gerçekleşmektedir. İşgörenlerin yoğun stres altında 
çalışmasına neden olan bu faktörler, çatışma yaşanması ihtimalini artırmaktadır. Alanyazında yapılan çeşitli çalışmalar, çatışmanın işletme performansını olumsuz yönde etkilediğini ortaya koymakla birlikte zaman içerisinde yapılan yeni çalışmalar göstermiştir ki doğru miktarda çatışma, başarıyla sonuçlanan kararların alınmasını sağlayabilmektedir (Shammugam ve Marimuthu, 2019: 158).

Havayolu sektöründe rekabetin şiddetinin yüksek olması (Küçükönal ve Korul, 2012: 89), kabin ekibi oluştulmasında kullanılan teknikler, ekip üyelerinin birbirlerinin kişilik özelliklerini önceden bilmiyor olma ihtimali ve meslekte geçirdikleri süre gibi nedenlerle kabin ekibi üyeleri arasında çatışma yaşanması ihtimali bulunmaktadır (Rubin vd., 1994: 119). Havayolunun karlılığı ve sürdürlebilirliği üzerinde önemli etkisi bulunan kabin ekibi üyeleri arasında çatışma yaşanması ve çatışmanın doğru yönetilememesi durumunda ekip içi iletişim ve uyum aksayarak, yolculara sunulan hizmetin kalitesini olumsuz yönde etkileyebilmektedir.

Havayolu işletmeleri, sundukları hizmet aracılığıly yüksek yolcu memnuniyeti sağlayarak rekabet avantajı kazanmak adına tecrübeli kabin görevlisi transferi arayışına girebilmektedir. Ayrıca, havayolunun mevcut kabin görevlileri arasında kabin amirliği poziyonuna terfi edebilmek için gerekli kriterleri sağlayamamıs sinyor kabin görevlileri bulunabilmektedir. Tecrübeli ve sinyor kabin görevlilerinin diğer kabin görevlileri ve kabin amiri ile aralarındaki yaş ve tecrübe farkı, kıdem derecesi, çalışılan pozisyon gibi faktörler ekip içerisinde çatışma yaşanmasına neden olabilmektedir.

Alanyazında, kabin ekiplerinde çatışma yönetimi hakkında sınırlı sayıda çalışma bulunmaktadır. Ayrıca, tecrübeli ve sinyor kabin ekipleri bağlamında çatışma yönetimi konusunu araştıran çalışmaya rastlanmamıştır. Araştırmanın amacı, tecrübeli ve sinyor kabin görevlilerinin ekipte bulunması durumunda kabin amirleri tarafından benimsenen çatışma yöntemlerini ortaya koyarak literature ve sektöre katkıda bulunmaktır. Bu amaç doğrultusunda öncelikle kabin ekibinin tanımı ve oluşumu, çatışma yönetimi kavramının genel çerçevesi ve kabin ekibi üyeleri arasında çatışma yöntemleri konularına yer verilmiş, sonrasında kalitatif çalışma yöntemlerinden yarı yapılandırılmış görüşme tekniği kullanılarak kabin amirlerinden elde edilen bulgular tartışılmıştır.

\section{KAVRAMSAL ÇERÇEVE}

\subsection{Kabin Ekibinin Tanımı ve Oluşumu}

Kabin görevlisi; "yolcu taşımacıllğı yapan hava araçlarında gerekli emniyet ve güvenlik önlemlerinin uygulanmasindan ve yolcu konforundan sorumlu kişileri” ifade etmektedir (SHGM, Kabin Memuru, 2019). Kabin görevlisi olarak istihdam edilen kişi zamanla işletme içi, ulusal ve uluslararası gereklilikleri karşılamasına bağlı olarak kabin amiri, eğitimci ya da kontrol kabin amiri gibi daha yüksek unvanlara hak kazanabilmektedir 
(Akpınar ve Erdağ, 2018: 91).

Kabin ekibi, dar gövde uçaklarda bir kabin amiri ve uçak tipine göre 2 ile 4 arasında değişen sayılarda kabin görevlisinden oluşmaktadır. Geniş gövde uçaklarda ise ekip oluşumu, biri sorumlu kabin amiri olmak üzere 22 kabin görevlisine kadar artan sayıda oluşturulabilmektedir (Shaw, 2007: 174).

Kabin ekibi oluşumunda uçak tipinin yanı sıra havayolunun benimsemiş olduğu iş modeli de etkili olmaktadır. Havayolları; tam hizmet sağlayıcı, düşük maliyetli, bölgesel, tarifesiz ve hava taksi olmak üzere genellikle beş farklı iş modelinden birini benimsemektedir (Koch, 2010: 54). Ayrıca son dönemde, tam hizmet sağlayıcı ile düşük maliyetli havayollarının bazı özelliklerini bir arada uygulayan ve hibrit adı verilen yeni bir iş modeli ortaya çıkmıştır (Avram, 2017: 149-154).

Havayolunun tam hizmet sağlayıcı iş modelini benimsemesi durumunda Porter' in odaklanma stratejisi ile de uyumlu olan iş ve ekonomi sınıfları ayrımına gittiği (Akdil ve Akpınar, 2016) ve hizmet kalitesini artırmak amacıyla uçak içerisinde istihdam ettiği kabin görevlisi sayısını artırdığı görülmektedir. Yine Porter' 1 n maliyet liderliği stratejisi ile uyumlu olan düşük maliyetli iş modelinde (Canöz, 2017: 194) ise tam hizmet sağlayıcılara göre daha az sayıda kabin görevlisi istihdam edilirken, bu eksiği kapatmak amacıyla kabin ekibinin sunduğu hizmetin kalitesinin artırılmasına çalışılmaktadır (Koch, 2010: 54).

\section{2 Çatışma Yönetimi}

Çatışma; kaynakların kıt olması, çıkarlarda uyumsuzluk ve farklı isteklerin yarattığı mücadele ortamından kaynaklanmaktadır. Bireyler arası ilişkilerde çatışma; sosyoekonomik durumun, inanışların, değer yargılarının, kültürün, kabiliyetlerin ve yaş gibi faktörlerin etkilediği bir süreçtir (Okçu vd., 2018: 42).

Alanyazında çatışma yönetimi hakkında; Mack ve Snyder, 1957; Deutsch ve Krauss, 1962, Walton ve McKersie, 1965, Pondy, 1967; Schmidt ve Kochan, 1972, Bacharach ve Lawler, 1981; Lewicki, 1997, Jehn ve Bendersky, 2003 ve Barki ve Hartwick 2004' ün çalışmaları yer almaktadır (Tjosvold, 2006: 89- 90). Mack ve Snyder, 1957, çatışmanın; diğer tarafları yok etmek, engellemek veya başka bir şekilde kontrol etmek için tasarlanmış davranışlar olduğunu ve çatışma ilişkisinin, tarafların yalnızca birbirlerinin pahasına kazanabileceği bir ilişki olduğunu ifade etmişlerdir (Mack ve Snyder, 1957: 218). Deutsch ve Krauss, 1962 ise çatışma durumunda, pazarlık yapanların bir anlaşmaya varma ihtimalinin anlaşmaya varılamamasına oranla daha olası olduğunu, çünkü ortak çıkarların birbirleriyle rekabet etme durumuna baskın geleceğini ileri sürmüşlerdir (Deutsch ve Krauss, 1962: 53).

Walton ve McKersie, 1965, çatışmanın iki alt boyutta değerlendirilebileceğini, ilk boyutta taraflar arasında çatışmanın sıfır toplamlı bir oyun olarak bir tarafın kazanırken diğer tarafın kaybetmesine neden olduğunu, ikinci boyutta ise iki tarafın da birleştirici bir yaklaşım benimseyerek ve kazan- kazan mantığına uygun davranışlar sergileyerek toplam 
kazanımı daha da artırılabileceğini ifade etmişlerdir (Burchill, 1999: 140).

Pondy, 1967, organizasyonların alt birimlerinde yaşanan çatışmayı; çıkar- grup ilişkisinin tarafları arasındaki pazarlık çatışması, üst- alt ilişkisinin tarafları arasındaki bürokratik çatışma ve yanal veya çalışma ilişkisinden kaynaklı sistemsel çatışma başlıkları altında tanımlanmıştır (Pondy, 1967: 296). Schmidt ve Kochan, 1972, çatışmayı, organizasyonel anlamda rekabetten ayırarak açıklamış, organizasyonlarda alt birimler arasında yaşanan hedef uyumsuzluğunun, algılanan fırsatların ve birbirine bağlı faaliyetlerin çatışma potansiyelini artırdığı ileri sürmüşlerdir (Schmidt ve Kochan, 1972: 359).

Barki ve Hartwick 2004, alanyazında yapılan çatışma tanımlarının; bilişsel, davranışsal ve duygusal üç ana boyut etrafında şekillendiğini, bunlardan bilişsel boyutun en sık tartışılan ve değerlendirilen kavram olduğunu, davranışsal boyutun, tartışma, rekabet, siyasi manevra, saldırganlık, düşmanlık ve yıkım gibi bir dizi farklı kişilerarası çatışma şekilleri ile ilişkilendirildiğini ve duygusal boyutun ise korku, kıskançlık, öfke, kaygı ve hayal kırıklığı gibi olumsuz duygularla açıklandığını ifade etmişlerdir (Hartwick ve Barki, 2004: 5).

Bacharach ve Lawler, 1981, çatışma durumunda pazarlık koşullarının belirlenmesi için güç bağımlılı̆̆ı teorisinin bir varyantını test etmişler ve kullanılabilecek taktikleri; kendini geliştirme, koalisyon, ayrılma tehdidi ve çatışmadan kaçınma olarak dört ana başlık altında toplamışlardır (Bacharach ve Lawler, 1981: 219). Lewicki, 1997, çatışma durumunda başarılı bir tartışmanın yürütülmesi için; konuyu anlamak ve tanımlayarak çerçevelendirmek, argümanlarını belirlemek ve ikna edici şekilde sunmak, etkili dinleme yaparak sorular sormak ve sonuçları analiz ederek üzerinde düşündükten sonra anlaşmaya varılmışsa bunu açıkca ilan etmek gerektiğini ileri sürmüştür (Lewicki, 1997: 253- 265).

Selami Sargut, 2015, bireylerin çatışma ile mücadele ederken; birleştiricilik, ödün verme, egemen olma, kaçınmacı ve uzlaşmacı olmak üzere beş farklı yöntem benimsediklerini ifade ederek, bu stiller arasında kazan- kazan yaklaşımına uygun olan birleştirici stilin çatışma yönetimi açısından en uygunu olduğunu belirtmiştir. Ödün verme, karşıdaki kişinin çıkarlarının öncüllenmesidir. Egemen olma, kişinin kendi çıkarılarını öncüllemesidir. Kaçınma, her iki tarafında çıkarlarının dikkate alınmayarak pasif kalınmasıdır. Uzlaşma ise karşılıklı çıkarların bir dengeye oturtulmaya çalışılmasıdır (Sargut, 2015: 179-182). Araştırmanın analizinde bu beş çatışma yönetimi yöntemi dikkate alınmıştır.

Jehn ve Bendersky, 2003, 1990 yılından önce örgütsel literatürün çoğunlukla çatışmayı verimsiz varsaydığını ve bir kısım akademisyenlerin çatışmanın yapıcı bir tarafının da olabileceğini öne sürseler de bu konuda ampirik çalışmalar yapmadıklarını belirtmişlerdir. Jehn ve Bendersky, ampirik çalışmalarının sonucunda, bir grubun yaşam döngüsü boyunca belirli seviyelerde çatışma yaşamasının yüksek performans ve yaratıcılığa yol açtığı sonucuna varmışlardır (Jehn ve Bendersky, 2003: 188- 228). 


\subsection{Kabin Ekibi Üyeleri Arasında Çatışma Yönetimi}

Havayolları, 20. yy’’ in son çeyreğinden itibaren insan faktörünün organizasyon içindeki öneminin artmasıyla birlikte uçuş ekipleri başta olmak üzere işgörenlerine Ekip Kaynak Yönetimi (CRM- Crew Resource Management) eğitimi vermeye başlamış, konu üzerine yapılan birçok araştırma sonucunda CRM eğitimleri uluslararası sivil havacılık otoriteleri tarafından zorunlu kılınmıştır (Monfries ve Moore, 1999: 26). Havayolları, Ekip Kaynak Yönetimi (CRM) eğitimi vererek işgörenlerinin iletişim, liderlik, takım çalışması ve koordinasyon becerilerini geliştirmeyi ve ekip çalışması esnasında üyeler arasındaki etkileşimlerin çözümünde çatışma yönetimi tekniklerini kullanmalarını sağlamayı amaçlamaktadır (Şekerli ve Gerede, 2011: 28).

Günümüzün şiddetli rekabet ortamında, hizmet kalitesinin artırılmasına katkı sağlayacağı düşüncesiyle havayollarının tecrübeli kabin görevlilerine olan talebi her geçen gün artmaktadır. Tecrübeli kabin görevlileri, daha iyi ücret, sosyal haklar veya pozisyon elde etmek amacıyla farklı havayollarına transfer olabilmektedir. Daha iyi ücret ve sosyal haklar için transfer olan tecrübeli kabin görevlileri, daha önce çalıştıkları havayolunda kabin amiri veya daha üst pozisyonlarda görev yapıyorken, transfer oldukları havayolunda kabin görevlisi olarak görev almayı kabul edebilmektedir (Shaw, 2007: 174). Bu durum, transferi gerçekleştiren havayolunun, mevcut kabin amirlerinin birçoğundan yaşça büyük ve tecrübeli kabin görevlisi istihdam etmesine neden olabilmektedir. Çalışmanın bu noktasından itibaren Tecrübeli Kabin Görevlisi ifadesi, diğer havayollarından transfer edilen kabin görevlileri için kullanılmaktadır.

Kabin ekipleri, kıdem (iş yerinde geçirilen süre, işe başlama tarihi) sıralaması dikkate alınarak ve kabin amirinden başlamak üzere yukarıdan aşağıya doğru hiyerarşik bir sıralama gözetilerek oluşturulmaktadır (Kasirzadeh vd., 2015: 5). Kabin amiri, ulusal ve uluslararası sivil havacılık otoritelerince belirlenmiş eğitimleri ve kontrol uçuşlarını başarıyla gerçekleştirmiş kıdemli kabin ekibi üyesidir (SHGM, Sht- Kabin Yol Boyu: 1). Havayolu işletmeleri uygulamada, sivil havacılık kurallarının gerektirdiği eğitim ve tecrübe şartlarına ek olarak, yabancı dil sınavından belirli bir seviyenin üzerinde puan alınması, belirli bir yaş aralığında olunması ve sivil havacılık otoriteleri tarafından şart koşulan minimum süreden daha uzun süredir kabin görevlisi olarak çalışıyor olunması gibi kriterler belirleyerek kabin amirliğine terfi kararı alabilmektedir (Kim ve Park, 2014: $50)$.

Havayolu, kabin amiri ihtiyacını iç kaynaklardan karşılamak istediğinde öncelikle işe başlama tarihi en eski olan kabin görevlilerini değerlendirmeye almaktadır, ancak yukarıda bahsedilen yasal ve işletme içi şartlar bu kabin görevlileri tarafından karşılanamadığında, işe giriş tarihi daha yeni olan kabin görevlilerinden başarılı olanlar kabin amirliğine terfi ettirilmektedir. Tecrübeli kabin görevlisi transferinde yaşanan artış ve mevcut kabin görevlileri arasında kabin amirliğine terfi gerekliliklerini karşılayamadığı için kabin görevlisi olarak çalışmaya devam eden yaşça büyük kabin görevlilerinin sayısının artması, kabin amiri ile ekip üyeleri arasında çatışma yaşanması ihtimalini artırmaktadır. 
Çalışmanın bu noktasından itibaren Sinyor Kabin Görevlisi ifadesi, havayolunun kabin amirliğine terfi edememiş mevcut kabin görevlileri için kullanılmaktadır.

Alanyazında, kabin ekibinde kabin amirinden daha tecrübeli bir kabin görevlisinin olması ile amirin ekibi üzerindeki hakimiyet düzeyi arasındaki ilişkiyi inceleyen doğrudan bir çalışma bulunmamakla birlikte konuyla dolaylı biçimde ilişkili çalışmalar yapıldığı görülmektedir. Örneğin; Peratanasumran ve Sitthichoke, Lufthansa’ da görevli Taylandlı ve Alman kabin ekipleri ile yaptıkları kalitatif çalışmalarında, farklı uyruklu kabin görevlilerinin bir arada çalışması durumunda kültürel farklılıklara bağlı çatışma yaşandığında hangi yöntemlerin tercih edildiğini belirlemeye çalışmışlardır. Tayland' $l_{1}$ kabin görevlilerinin rekabetçi yöntemi, Alman kabin görevlilerinin ise uzlaşmacı yöntemi tercih ettiklerini tespit etmişlerdir. Çalışma, kültürel farklılıklar düşünülerek yapılmışsa da yaş ve tecrübe konuları dolaylı biçimde çalışmayı etkileyen unsurlar olmuştur (Peratanasumran ve Sitthichoke, 2015: 18-25).

\section{ARAŞTIRMANIN AMACI, ÖNEMİ VE PROBLEMİ}

Farklı tecrübe ve kıdeme sahip kabin görevlilerinin tutum ve davranışlarının araştırılması ve kabin amirlerinin benimsedikleri çatışma yöntemlerinin belirlenmesi, ekip içi uyumun sağlanarak algılanan hizmet kalitesinin yüksek düzeyde tutulması açısından önem arz etmektedir.

Alanyazında kabin ekiplerine yönelik çatışma yönetimi çalışmaları çoğunlukla kabin ekibi ile yolcular arasındaki çatışma ve kokpit ekibi ile kabin ekibi arasındaki çatışma olmak üzere iki başlık alıında toplanmaktadır. Araştırmanın önemi, kabin ekibi üyeleri arasında yaşanan problemlerde çatışma yönetiminin nasıl uygulandığı hakkında sınırlı sayıda çalışma bulunan ve tecrübeli ve sinyor kabin görevlileri kapsamında kabin ekibi üyeleri arasında çatışma yönetimi hakkında çalışmaya rastlanılamayan alanyazına ve dolayısıyla sektöre katkıda bulunmasıdır.

Araştırmanın problemi, havayollarının transfer ettikleri tecrübeli kabin görevlilerinin ya da kabin amiri olabilmek için gerekli yabancı dil yeterliliği, eğitimlerde başarı durumu, işe devamlılık oranı gibi işletme içi şartları yerine getiremediği için kabin amirliğine terfi edemeyerek kabin görevlisi olarak görev yapmaya devam eden sinyor kabin görevlilerinin, görevlendirildikleri uçuşlarda kabin amirinden daha tecrübeli ve yaşça büyük olmaları durumunda amirin ekip üzerindeki hakimiyetini olumlu ya da olumsuz açılardan etkileyebilecek olmalarıdır. Kabin amirinin yetki ve sorumluluğu altında çalışan tecrübeli ve sinyor kabin görevlilerinin, kabin görevliliği mesleğine, havayolunun prosedürlerine ve çalışma talimatlarına olan hakimiyetleri ve görev süresince yaşanan aksaklıklara karşı farkındalık seviyeleri diğer ekip üyelerine oranla daha yüksek olabilmektedir. Bu durumda tecrübeli ve sinyor kabin görevlileri, kabin amirine yönetsel kararlarında destek vererek ve diğer kabin görevlilerine yön göstererek, amirin ekip üzerindeki hakimiyetini olumlu 
açıdan etkileyebilmekte ya da hata arayışı içinde olup üstlerine raporlamak gibi çeşitli davranışlar sergileyerek ekip üyeleri arasında çatışma yaşanması ihtimalinin artmasına neden olabilmektedir.

\section{ARAŞTIRMANIN YÖNTEMI}

Çalışma, Türkiye’ de faaliyet gösteren özel bir havayolu işletmesinde kalitatif araştırma yapılarak gerçekleştirilmiştir. Kalitatif araştırmalar, özellikle kasti örnekleme yöntemiyle birlikte, az sayıda katılımcıdan konu hakkında derinlemesine ve çok miktarda bilgi elde edilebilmesine imkan tanımaktadır (Curtisa vd., 2000: 1002). Çalışmada, kasti örneklem seçim yöntemi kullanılarak havayolunun en az iki yıllık kabin amirliği tecrübesine sahip 10 kabin amiri ile yarı yapılandırılmış görüşmeler yapılmıştır.

Kalitatif araştırmalar, bireylerin veya grupların sosyal veya insani bir soruna atfettikleri anlamları araştıran varsayımlarla başlamaktadır. Araştırmacılar, bu sorunu incelemek için konuyla ilgili insanlara ve yerlere duyarlı doğal bir ortamdan veri toplayarak ve tümevarımsal modeller veya temalar oluşturarak verileri analiz etmektedir. Çalışmanın sonucu; katılımcıların seslerini, araştırmacının yansımasını ve sorunun karmaşık bir tanımını ve yorumunu içererek alanyazına katkıda bulunmaktadır (Creswell, 2007: 37).

Kalitatif araştırmalar; derinlemesine görüşme, gözlem ve yayınlanmış dokümanların incelenmesi gibi yöntemlerle gerçekleştirilir. Derinlemesine görüşme, soruların açık uçlu sorulduğu ve araştırılan konu hakkında detaylı bilgi edinilmesi sağlayan bir veri toplama tekniğidir (Tekin, 2006: 101).

Görüşme yöntemi kullanılması durumunda bireylerin konu hakkındaki düşüncelerinden, hissettiklerinden ve tecrübelerinden doğrudan yararlanılabilmektedir (Patton, 2014: 4). Görüşmenin dizaynı ve kullanılan soru cümleleri, verilebilecek cevapların esnekliğini ve derinliğini etkileyebilmektedir. Derinlemesine görüşme için kullanılan teknikler; yapılandırılmış, yarı yapılandırılmış ve yapılandırılmamış olmak üzere üçe ayrılmaktadır (Mathers vd., 1998: 4).

Yarı yapılandırılmış görüşme tekniği, soruların görüşmeden önce belirlenmesine karşın görüşme esnasında duruma göre farklı soruların ilave edilebilerek daha derin bilgilere ulaşılmasına imkan veren görüşme tekniğidir. Ayrıca, sorulması önceden planlanan ancak cevabının başka soruların içerisinde verildiği düşünülen sorular görüşmeden çıkartılabilir. Görüşme teknikleri içerisinde, sağlamış olduğu esneklik ve daha derin bilgi edinebilme özellikleri nedeniyle sıklıkla kullanılmaktadır (Tümüklü, 2000: 547). Yarı yapılandırılmış görüşme tekniğine uygun olarak çalışmada kullanılmak üzere hazırlanmış sorular EK- 1' de verilmiştir.

EK-1' de verilen görüşme soruları, kabin ekipleri hakkında alanyazında yayınlanan 
çalışmalardan ve ikincilveri niteliğindeki CRM eğitimleri dokümanlarından yararlanılarak, ayrıca ülkemizde faaliyet gösteren özel bir havayolunda kabin ekipleri müdürlügü yapmış bir yönetici ile ülkemizde faaliyet gösteren bir havayolunda kabin ekibi eğitmenliği görevinde bulunmuş ve halen yurtdışında faaliyet gösteren özel bir havayolunda kabin ekipleri müdür yardımcısı olarak çalışan bir yöneticinin önerileri dikkate alınarak hazırlanmıştır. Söz konusu sorular açık uçlu hazırlanarak, kabin amirlerinin ekiplerinde kendilerinden yaşça büyük ve daha tecrübeli kabin görevlileriyle çatışma yaşamaları durumunda hangi çatışma yönetimi tekniklerini tercih ettikleri hakkında derinlemesine bilgi elde edilmesine çalışılmıştır.

Kabin amirleri ile yapılan görüşmelerde araştırmanın konusuyla ilgili bilgilendirme yapılmıştır. Kayıt cihazı kullanılacağı söylenerek, görüşme sonlandıktan sonra dinleyebilecekleri ve uygun bulmadıkları söylemlerini çıkartabilecekleri hakkında güvence verilmiştir. Talep etmeleri nedeniyle katılımcıların isimleri yerine kendileri için atanacak bir kod kullanılacağ 1 söylenmiştir. Bu bilgilendirmeyle, araştırmanın kabin amirleri üzerinde çekince yaratması engellenmeye çalışılmıştır. Görüşmeler, kabin amirlerinin kendini rahat hissettiği, iletişimi bozacak dış etkenlere sebebiyet vermeyen ortamlarda, 19.11.2019 ile 02.12.2019 tarihleri arasında gerçekleştirilmiştir. Görüşmeler esnasında kabin amirlerini yönlendirecek şekilde soru sorulmamasına dikkat edilmiştir.

\section{ARAŞTIRMA VERILERINIIN ANALIZİ VE BULGULARI}

Yarı yapılandırılmış görüşme tekniğiyle elde edilen verilere içerik analizi yapılarak kodlar atanmış ve aralarındaki ilişkilerin belirlenmesi yoluyla temalar oluşturulmuştur. Kodlar ve temalar, düzenleme işleminden sonra değerlendirilerek yorumlanmıştır (Özdemir, 2010: 332). Kabin amirlerinin demografik bilgileri ve tecrübe düzeyleri EK- 2' de gösterilmektedir.

Araştırmaya katılan kabin amirlerinin 4' ü erkek, 6’ sı kadınlardan oluşmaktadır. Araştırma grubunun yaş aralığı 28- 40 yaş arasında değişmektedir ve yalnız 4’ ü 35 yaşın üzerindedir. Kabin amirliğinde geçirdikleri toplam süre 3 ile 12 yıl arasında değişmektedir ve grup çoğunluğu 6- 8 yıl arası tecrübeye sahiptir. Kabin amirlerinin, kabin görevlisi olarak toplam tecrübeleri 5 ile 15 yıl arasında değişmektedir. Grubun çoğunluğu 8- 10 yıl arası toplam tecrübeye sahiptir. Katılımcıların tamamı daha önce başka bir havayolunda çalışmamıştır. Kabin amirlerinin yarı yapılandırılmış görüşmede verdikleri cevaplar örnek olarak sunulurken, gizlilik esasına dayanılarak katılımcılara KA1' den KA10' kadar kod verilmiştir.

Kabin amirleriyle yarı yapılandırılmış nitelikte gerçekleştirilen görüşmeler sonucunda elde edilen kodlar iki ana tema etrafında birleşmektedir:

1) Kabin amirlerinin, tecrübeli kabin görevlisi transferiyle gelen yaşça büyük ve tecrübeli 
kabin görevlilerine dair duygu ve düşünceleri ile ekip çalışması esnasında çatışma yaşama ihtimallerine ilişkin görüşleri,

2) Kabin amirlerinin, havayolunun mevcut kabin görevlileri arasında kabin amirliğine terfi edememiş yaşça büyük ve tecrübeli kabin görevlilerine dair duygu ve düşünceleri ile ekip çalışması esnasında çatışma yaşama ihtimallerine ilişkin görüşleri.

Grafik 1' de kabin amirlerinin, tecrübeli ve sinyor kabin görevlilerine dair duygu ve düşünceleri ile ekip çalışması esnasında çatışma yaşama ihtimallerine ilişkin görüşlerinden elde edilen kodların dağılımı gösterilmektedir.

Grafik 1: Kabin Amirlerinin, Tecrübeli Ve Sinyor Kabin Görevlilerine Dair Duygu Ve Düşünceleri İle Ekip Çalışması Esnasında Çatışma Yaşama İhtimallerine İlişsin Görüşleri

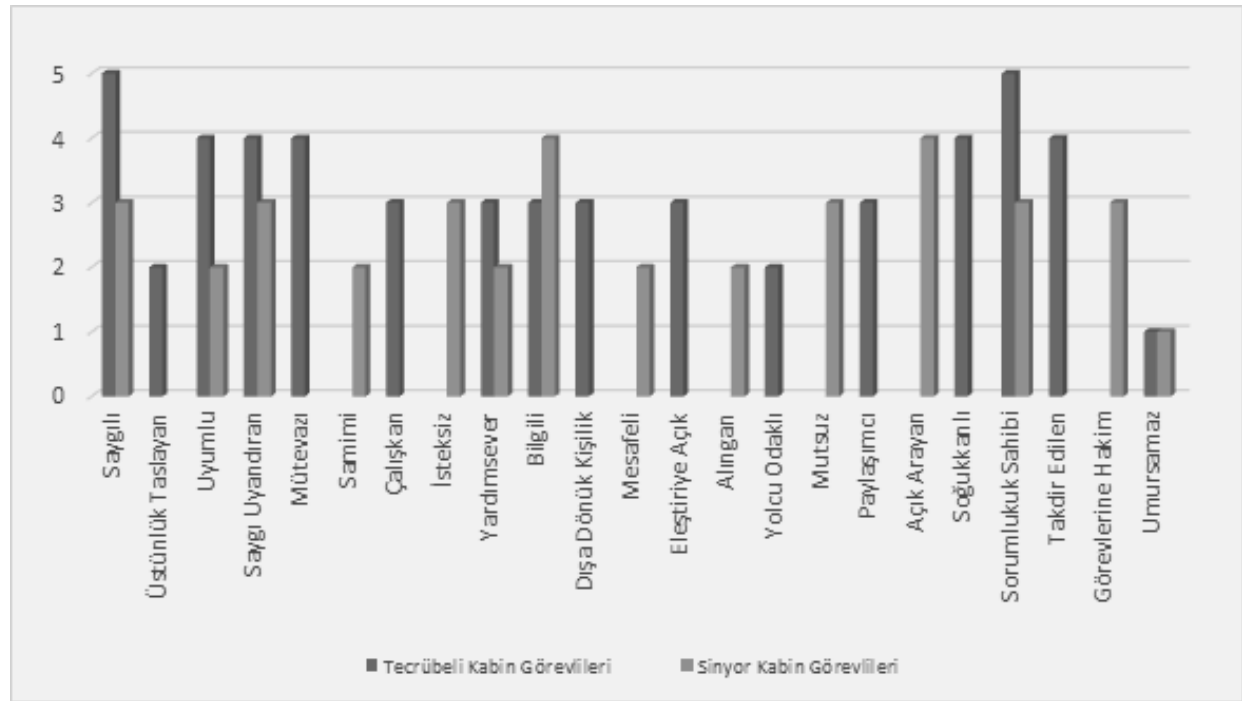

Kabin amirlerinin, tecrübeli kabin görevlilerine karşı duygu ve düşünceleri ile ekip çalışması esnasında çatışma yaşama ihtimallerine ilişkin görüşlerini belirten kodlamış 16 adet ifade olduğu görülmektedir. Belirlenen kodlar ve (f) ile ifade edilen tekrar sıklıkları; saygılı $(\mathrm{f}=5)$, sorumluluk sahibi $(\mathrm{f}=5)$, uyumlu $(\mathrm{f}=4)$, saygı uyandıran $(\mathrm{f}=4)$, takdir edilen $(\mathrm{f}=4)$, mütevazi $(\mathrm{f}=4)$, soğukkanlı $(\mathrm{f}=4)$, çalışkan $(\mathrm{f}=3)$, eleştiriye açık $(\mathrm{f}=3)$, yardımsever $(\mathrm{f}=3)$, paylaşımcı $(\mathrm{f}=3)$, bilgili $(\mathrm{f}=3)$, dışa dönük kişilik $(\mathrm{f}=3)$, yolcu odaklı $(\mathrm{f}=2)$, üstünlük taslayan $(\mathrm{f}=2)$ ve umursamaz $(\mathrm{f}=1)$ olarak siralanmaktadır.

Kabin amirleriyle yapılan görüşmelerde, transfer yoluyla gelen tecrübeli kabin görevlilerinin dişa dönük, iletişime açık, saygılı, mütevazi tavırlar sergileyerek ekip içi uyumun artmasına katkıda bulundukları belirtilmiştir. Örneğin KA4, tecrübe ve yaş olarak sizden büyük kabin görevlilerinin, sizinle ve diğer kabin görevlileriyle iletişimi, 
diğer kabin görevlilerinin sizinle ve kendi aralarındaki iletişimleri ile aynı şekilde mi gerçekleşiyor şeklinde kendisine yöneltilen soruya, "Kabin görevlisinin farklı bir şirketten tecrübeli olarak geldiğini henüz ekip odasındayken anlayabiliyorum. Hem bazılarının yaş itibariyle büyük olduğu belli oluyor hem de benimle ve diğer ekip üyeleriyle olan iletişimleri farklı. Çoğunluğu gülümseyerek sıcak tavırlar sergiliyor, brifing öncesinde konuşkan davranarak ekibi kaynaştırıyor. Bir konu hakkında konuştuklarında ya da brifingde söz aldıklarında kendilerinden emin bir duruşları oluyor ve herkese karşı oldukça saygılı davranıyorlar" cevabını vermiştir. KA7 ise aynı soruyu, "Tecrübeli gelen kabin görevlilerin çoğu ben sormadan tecrübeli olduğunu söylemiyor. Ancak ben konuşmasından, duruşundan, gülümsemesinden ve saygıl davranışlarından anlayarak kendisine sorduğumda tecrübeli olduğunu öğreniyorum" diyerek cevaplamıştır.

Katılımcılar ayrıca transfer yoluyla gelen tecrübeli kabin görevlilerinin çoğunluğunun ekip arkadaşlarının motivasyonunu ve yolcuya sunulan hizmet kalitesini artırmaya yönelik davranışlar sergilediklerini ve diğer kabin ekiplerinden daha fazla çalıştıklarını ifade etmişlerdir. Örneğin KA2, ekibinizde sizden daha tecrübeli ve yaşça büyük bir kabin görevlisi olmasının, aranızda problem yaşanmasına neden olacak düzeyde, sizin ve diğer kabin görevlilerinin üzerinde gerginliğe neden olduğunu düşünüyor musunuz sorusuna, "Ĕ̆er bu soruyu tecrübeli kabin görevlileri için soruyorsanız çoğunluğunun benimle ve diğer ekip üyeleriyle iletişimi çok iyi. Bu kabin görevlileriyle gerçekleştirdiğim uçuş görevlerinin hiçbirinde ekiple ilgili sorun yaşamadım. Ekip arkadaşı ile anlaşmazlıkyaşayan kimse olmad,, tam tersine ekibin havası değişiyor, daha motivasyonlu ve iyi anlaşan bir ekip oluyorlar" cevabını vermiştir. KA8, tecrübeli kabin görevlileri için "Ekibimde tecrübeli kabin görevlisi olduğunda yolcuyla sorun yaşamıyorum. Çoğu problemi bana çözdükten sonra iletiyorlar. Zaten çoğunluğu eskiden amirlik yapmış kişiler. Kiminle nasıl konuşacaklarını, yolcu taleplerine karşı ne tür öneriler sunarak yolcuyu memnun edeceklerini biliyorlar. Birçok kabin görevlisinin aksine sık sık kabinde dolaşarak yolcuyla sohbet ettiklerini görüyorum, uçuş boyunca istekli çalışıyorlar" demiştir.

Katılımcıların çoğunluğu tarafından, tecrübeli kabin görevlilerinin, uçuşta acil bir durum yaşanması durumunda kabin amirlerinde güven uyandıran bir soğukkanlılığa sahip oldukları sıklıkla tekrarlanmıştır. KA9, tecrübeli kabin görevlisi olarak transfer edilen kabin görevlileriyle mi yoksa sizinle aynı havayolunda sizden daha önce işe başlamış ancak kabin amirliğine terfi ettirilmemiş kabin görevlileriyle mi görev yapmayı tercih edersiniz sorusuna "Tercih hakkım olsaydı transfer yoluyla gelmiş olan kabin görevlisini seçerdim. Bu cevabı verirken genelleme yaptı̆̆ımı bilmenizi isterim. Elbette işinde çok istekli ve başarılı sinyor kabin görevlileri ile de uçuş görevleri yaptığım oluyor. Ancak genellediğimde tecrübeli kabin görevlilerinin uçuşun başından sonuna kadar atik davrandıklarını söyleyebilirim. Diğer kabin görevlilerine nazaran farkındalıkları oldukça yüksek. Örneğin, yolcuya ilk yardım gerektiren durumlarda oldukça hızlı davranarak müdahale ettiklerine birkaç kez şahit oldum. Kontrolü ele alı, soğukkanlllikla gereken görevleri hem kendileri yerine getiriyor hem de ekip arkadaşlarını yönlendiriyorlar" cevabını vermiştir. KA1, tecrübeli kabin görevlileri hakkındaki düşüncesini "İstekli ve çalışkan oluşlarıyla birlikte tecrübelerini ekip üyeleriyle sürekli paylaşmaları bende güven duygusu oluşturuyor. Özgüvenli ve soğukkanlı 
bir duruşları var, bu uçuşta bir tehlike yaşasak diğer kabin görevlilerini ve yolcuları yönlendirir diye düşündüğ̈üm oluyor" şeklinde ifade etmiştir.

Görüşmelerde az sayıda tekrar etmekle birlikte, tecrübeli kabin görevlilerinin zaman zaman verilen emirlere karşı direnç göstererek umursamaz gözükmeye çalıştıkları ve bazı konularda üstünlük taslar şekilde konuşmalar yaptıkları belirtilmiştir. Örneğin KA6, tecrübeli kabin görevlisi olarak transfer edilen kabin görevlileriyle mi yoksa sizinle aynı havayolunda sizden daha önce işe başlamış ancak kabin amirliğine terfi ettirilmemiş kabin görevlileriyle mi görev yapmayı tercih edersiniz sorusuna, "Her iki kabin görevlisinin de ekibimde olmasını tercih etmezdim. Ekibimde yaşça benden büyük ve daha tecrübeli biri olmadığında uçuşlarım daha iyi geçiyor. Tecrübeli ya da sinyor kabin görevlilerinin kendilerinden daha az tecrübeye sahip kabin amirlerini fazla ciddiye almadikların düşünüyorum ve uçuş süresince verdiğim kararların sorgulandığını hissediyorum. Ancak tecrübeli kabin görevlilerinin, sinyor kabin görevlilerine oranla iletişime daha açık olduğunu gözlemliyorum. Sinyor kabin görevlilerine bir görev verdiğimde tecrübeli kabin görevlilerine oranla yüzlerinin daha çabuk asıldığını ve genellikle daha umursamaz göründüklerini söyleyebilirim. Yine de her ikisi de verdiğim işim nasıl daha iyi yapılabileceği konusunda fikirlerini ileri sürmekten geri kalmıyorlar. Kabin görevlisinin benimle olan iletişimine, bana ve ekip arkadaşlarına olan saygısına ve davranışlarına göre kabin amiri olarak gücün bende olduğunu hatırlatmam gereken zamanlar olabiliyor" cevabını vermiştir.

Araştırmaya katılan kabin amirleri, tecrübeli kabin görevlilerinin geçmiş mesleki tecrübelerini ve yaşça kendilerinden ya da diğer ekip üyelerinden büyük olmaları durumlarını göz önüne alarak, çok önemli olmadığı sürece uçuş görevi esnasında karşılaştıkları hataları genellikle söylememeyi tercih ettiklerini söylemişlerdir. Bu durum, kabin amirlerinin yaşa ve tecrübeye duydukları saygılarının yanında karşı tarafın dışa dönük, uyumlu ve saygılı tavırlar sergilemelerinden kaynaklanmaktadır.

Örneğin KA3, tecrübeli kabin görevlisi olarak transfer edilen kabin görevlileriyle mi yoksa sizinle aynı havayolunda sizden daha önce işe başlamış ancak kabin amirliğine terfi ettirilmemiş kabin görevlileriyle mi görev yapmayı tercih edersiniz sorusuna "Transfer yoluyla gelen kabin görevlileri rahatlıkla ayırt edilebiliyorlar, yaşıtları ile karşılaştırıldığında motivasyonları oldukça yüksek. Neredeyse her işe koşuyorlar, daha genç olan kabin görevlilerine göre daha saygllılar ve ekip arkadaşlarına yardımcı oluyorlar" cevabını vermiştir. Ekibinizdeki tecrübeli ve yaşça büyük kabin görevlisinin, hatalı ya da takdir gerektiren davranışlarını kendisine bildiriyor musunuz, bilgilendirme yaparken kendinizi rahat hissediyor musunuz sorusunu ise "Kabin görevlisi benden yaşça büyükse bunu elbette önemsiyorum ancak uçuşun emniyetli bir şekilde ve yolcu memnuniyetinin sağlanarak tamamlanması benim sorumluluğumda. Genellikle, çok bacaklı ya da uzun sürecek bir uçuş yapacaksak kabin görevlisinin motivasyonunu bozmamak adına henüz görevin ilk saatlerinde gerçekleşen ancak emniyeti ve yolcu konforunu ciddi ölçüde etkilemeyen hataları uçuş sonrası yaptığımız brifinge bırakırım. Önemli gördü̈̆̈̈m hataları ise bekletmeden söylerim. Açıkçası, yaşı benden büyük ve daha tecrübeli bir kabin görevlisinin yapmış olduğu hata bu şekilde sonraya bırakılabilecek türdense kişinin davranışlarına bakıyorum. Saygılı, 
çalışkan, istekli bir kabin görevlisi olması durumunda biraz da empati kurarak ve belirli bir yaştan sonra eleştirilmenin genç yaşa göre daha rencide edeceğini düşünerek uçuş sonunda hata konusunu dile getirmediğim zamanlar oluyor" şeklinde cevaplamıştır.

Yukarıda bahsi geçen 16 kodlanmış ifade ve katılımcıların verdikleri cevaplar yorumlandığında, araştırmaya katılan kabin amirlerinin çoğunluğunun ekipte tecrübeli kabin görevlisi bulunması durumunda kendini daha rahat hissettiği ve bu kişilerin bilgi ve tecrübelerini kendileriyle paylaşıyor olmalarından memnuniyet duyduğu görülmektedir. Sonuç olarak, transfer yoluyla gelen yaşça büyük ve daha deneyimli kabin görevlileriyle çok sık çatışma yaşanmadığı ve yaşan çatışmalarda da kabin amirlerinin genellikle uzlaşmacı bir tavır sergilemeyi tercih ettikleri anlaşılmaktadır.

Kabin amirlerinin, sinyor kabin görevlilerine dair duygu ve düşünceleri ile ekip çalışması esnasında çatışma yaşama ihtimallerine ilişkin görüşlerini belirten kodlanmış 14 adet ifade tespit edilmiştir. Belirlenen kodlar ve (f) ile ifade edilen tekrar sıklıkları; bilgili ( $\mathrm{f}=$ 4), açık arayan $(\mathrm{f}=4)$, saygılı $(\mathrm{f}=3)$, mutsuz $(\mathrm{f}=3)$, sorumluluk sahibi $(\mathrm{f}=3)$, isteksiz $(\mathrm{f}=3)$, saygı uyandıran $(\mathrm{f}=3)$, görevlerine hakim $(\mathrm{f}=3)$, alıngan $(\mathrm{f}=2)$, mesafeli $(\mathrm{f}=2)$, uyumlu $(\mathrm{f}=2)$, samimi $(\mathrm{f}=2)$, yardımsever $(\mathrm{f}=2)$, umursamaz $(\mathrm{f}=1)$ olarak siralanmaktadır.

Kodlanmış ifadeler incelendiğinde, araştırmaya katılan kabin amirlerinin çoğunluğunun, sinyor kabin görevlileri ile aralarındaki yaş ve tecrübe farkından dolayı hoşgörülü bir tavır sergilemeleri beklenmesine karşın, bu kişilerle birlikte görev yapma konusunda çekinceleri olduğu görülmektedir. Örneğin KA5, ekibinizde sizden yaşça büyük ve tecrübeli kabin görevlisi olması durumunda yaşadığınız problemler nelerdir sorusuna, "Uçtuğum ekiplerle çok sık sorun yaşadiğımı söyleyemem ancak yaşça büyük olup kabin amiri olamamış birkaç kabin görevlisiyle gerginlik yaşadı̆̆ım uçuşlarım oldu. Bu gerginliklerden biri, ben henüz kabin amiri olmadan önce yaptığımız bir uçuşta benden daha kıdemli olduğu için kabinin arka tarafinın sorumlusu olarak görevlendirilen bir kabin görevlisiyle, ben kabin amiri olduktan sonra gerçekleştirdiğimiz bir uçuşta yaşanmıştı. Uçuş boyunca aramıza mesafe koyarak, asık bir yüz ifadesi takındığını ve beni görmezden gelmeye çalıştı̆̆ını hatırlıyorum. Benim ona kıyasla daha az tecrübeli olmamın ve daha önce birlikte uçuş yaptı̆̆ımızda benden sinyor olmasinın, beni kabin amiri olarak benimseyememesin sebebi olduğunu düşünüyorum. Maalesef ikimiz arasında yaşanan bu gerginlik diğer ekip arkadaşlarımızı da etkilemişti ve sanırım hepimiz uçuşun bir an önce bitmesini istemiştik" cevabını vermiştir.

KA10, sinyor kabin görevlileri hakkındaki düşüncelerini “Tecrübeli olmalarına karşın kabin amiri olamamış kabin görevlileri genellikle düşük bir motivasyona sahip oluyorlar. Bazıları mümkün olduğunca iletişimden uzak duruyor, bazıları ise görevlerini yerine getirirken umursamaz bir tavır sergiliyor. Kıdemleri yüksek olduğundan neredeyse tüm uçuşlarında amirden sonraki ilk memur oluyorlar ve ben çoğu kez diğer kabin görevlisi arkadaşlarm iş yükünün arttı̆̆ını fark ediyorum. Tabii ki içlerinde son derece saygılı, çalışkan ve sicakkanlı olan sinyor kabin görevlileri de var ancak objektif düşündüğümde ylllarca emek verip, kabin amirliği pozisyonuna göre daha çok fiziksel güç gerektiren kabin memurluğu görevinde takılı kalmak gerçekten moral bozucu bir durum olabilir. Yaş ilerledikçe sizden yaşça küçük 
kişilerin emrinde çalışmak da insanı zorlayıcı bir durum. Bunların farkındayım ama hem ekipteki diğer kabin görevlilerinin motivasyonunu düşünmek zorundayım hem de o kişinin kabin amiri olamamasının sorumlusu ben olmadiğıma göre bu tutum ve davranışlara katlanmama gerek olmadığını düşünüyorum" şeklinde ifade etmiştir.

KA4, sinyor kabin görevlileri hakkındaki düşüncelerini açıllarken "Kabin amiri olamamış bazı sinyor kabin görevlileri ile uçuş yaptı̆̆ımızda bazen izlendiğim duygusuna kapılıyorum. Yolcuya anons yaparken ses tonumun nasıl olduğu, ekipteki diğer kabin görevlilerine nasıl davrandığım, kokpit ekibiyle olan iletişimim, yolcuya karşı tavrım, üniformamın, saçımın, makyajımın uçuşa uygunluğu gibi konularda tedirginlik yaşadığım zamanlar oluyor. Ekibimdeki sinyor kabin görevlisiyle yakınlık kurmaya çalıştı̆̆ımda sonuç alamıyorsam bu uçuşta her zamankinden daha dikkatli olup açık vermemeliyim diye düşünmeye başlıyorum ve bende ister istemez uçuş boyunca o kabin görevlisini daha dikkatli gözlemliyorum" demiştir.

KA1, uçuş görevinde sizden yaşça büyük bir ekip üyesiyle liderliğiniz konusunda mücadele etmeyi uygun bulur musunuz, uygun görüyorsanız liderin kim olduğunu gösterme çabasına giriyor musunuz, uygun görmüyorsanız o uçuş görevi boyunca tecrübeli ve yaşça büyük kabin görevlisini idare ederek tartışmayı uzatmamayı mı seçiyorsunuz sorusuna, "Yaşça benden büyük ve tecrübeli olup da kabin amiri olamamış bazı sinyor kabin görevlileri ile aramızda küçük çaplı bir rekabet olduğunu söyleyebilirim. Örneğin yurtdışına yaptığımız uçuşlarda havalimanında bekleme süresi varsa duty free' ye alışverişe gitmek için sorumlu kaptanın iznini alırız. Bu izin alma işi elbette ki kabin amirindedir çünkü kabin görevlileri öncelikle kabin amirine fikrini sormal ve kabin amiri yolcu hazırliğı için yeterli bekleme süresi olduğuna kanaat getirirse kaptanın izni istenmelidir. Birkaç kez bana sorulmadan kaptandan izin istenmesi durumunu yaşadım ve beni baypas ederek kaptandan izin isteyen bu kişilerin çoğunluğu sinyor kabin görevlileriydi. Bence bunun en önemli nedeni, firsatını bulduklarında ve sınırı da çok aşmadan, rakip olarak gördükleri kabin amirine karşı bir üstünlük sağlama ve kontrolü ele alabileceklerini gösterme çabası. Ben bu tür durumlarla karşılaştığımda kontrolün bende olduğunu göstermekten geri durmuyorum" cevabını vermiştir.

Ayrıca, sıklığı az olmakla birlikte, araştırmaya katılan kabin amirlerinden bazıları, söz konusu sinyor kabin görevlilerinden samimi, sorumluk sahibi ve yardımsever kişiler olarak bahsetmiştir. KA7, ekibinde sinyor kabin görevlisi olması hakkındaki görüşlerini, "Çeşitli sebeplerle kabin amiri olamamış ve emek verdiğimiz bu havayolunda yıllarını geçirmiş arkadaşların meslekten vazgeçmeyerek kabin görevlisi olarak çalışmaya devam etmeleri bile benim açımdan takdir edilmesi gereken bir durum. Herkesin, bu arkadaşlar gibi terfi alamadan ve tecrübesi kendinden daha az olan amirlerle birlikte çalışmay kabul edeceğini düşünmüyorum. Sinyor kabin görevlileri ile gerçekleştirdiğim uçuşlarda özgüvenli, ilgili ve yardımsever davranışlarda bulunduklarını gözlemledikçe mesleğe olan saygılarından dolayı bende kendilerine saygı duyuyorum" diyerek ifade etmiștir.

Kabin amirlerinin çoğunluğu, sinyor kabin görevlilerinin kendilerinden uzun süredir bu 
havayolunda çalıştığını ve işin gerekliliklerini çok iyi bilmeleri gerektiğini öne sürerek, mesleki hatalarını göz ardı etmeye isteksiz olduklarını ifade etmişlerdir. Örneğin KA2, "Birlikte uçuş yaptı̆̆ım bazı sinyor kabin görevlilerinin bana ve ekipteki diğer kabin görevlilerine karşı mesafeli oluşunun ve kimi zaman yönetim tarzımı beğenmediklerini düşündürten tutum ve davranışlarının sebebinin, kendilerini mesleğin bir uzmanı gibi görmeleri olduğunu düşünüyorum. Kabin ekibi üyesi olmak, her bir uçuş görevinde çok sayıda yolcuyla etkileşim halinde olmayı ve yüksek bir tempoda çok sayıda işin peş peşe yapılmasını gerektiriyor. Bu derece yüksek bir tempoda çalışırken bazı işlerin atlanabilmesi, hataların yapılması oldukça doğal. Ekip olarak çalışabilmekte bence bu noktada önem kazanıyor. Hem birbirimizin eksiğini kapatarak işin doğru yapılmasın sağlayabilmek için hem de yeri geldiğinde belirli sınırlar çerçevesinde birbirimizin açı̆̆ını kapatabilmek için iyi bir iletişime ve uyuma ihtiyacımız var. Ben sizden daha iyi biliyorum düşüncesiyle ekiple araya mesafe koyan kişinin hata yapma lüksü olmamalı. Dolayısıyla bende bu tarz davranışlarda bulunan sinyor kabin görevlilerinin herhangi bir hatasını gördüğ̈̈mde direkt uyarıyorum ve hatasını mümkün olduğunca düzeltmesini talep ediyorum" şeklinde düşüncelerini açılamıştır.

Katılımcıların cevapları ve kodlanmış ifadeler incelendiğinde, sinyor kabin görevlileri ile kabin amirleri arasındaki çatışmanın, sinyor kabin görevlilerinin kabin amirine ve diğer ekip üyelerine karşı mesafeli duruşundan, çoğu zaman umursamaz, isteksiz ve mutsuz tavırlar sergilemelerinden, aralarında dile getirilmemiş bir rekabetin varlığından ve her iki tarafında kendisinde hata arandığını düşünmesinden kaynaklandığı anlaşılmaktadır. Yapılan hataların önem derecesi fark etmeksizin göz ardı edilmemesi ve liderlik gücünün otoriteyi sağlamak için kullanılması, kabin amirlerinin, sinyor kabin görevlileri ile yaşadıkları çatışmalarda egemen olma yöntemini benimsediklerini ortaya koymaktadır. Kabin amirleri, ekiplerine karşı normalde olduklarından daha mesafeli davranarak ve hiyerarşinin sağladığı yetkiyi kullanarak ekip üzerindeki hakimiyetlerini korumaya çalışmaktadır.

\section{TARTIŞMA}

Havayolu sektörü, kuruluşundan bugüne birçok savaş ve ekonomik krizle karşılaşmasına rağmen, her bir savaş ve ekonomik kriz sonrasında eskiye oranla daha hızlı büyümüştür. Bu hızlı büyüme ve artan rekabetin şiddeti, havayollarını, rakiplerinden daha iyi hizmet sunarak rekabet üstünlüğü sağlamaya yönlendirmiştir. Dolayısıyla, havayolunun sunduğu hizmetin temsilcisi olan kabin ekiplerinin önemi ve özellikle tecrübeli kabin görevlilerine olan talep gittikçe artmıştır.

Kabin görevliliği mesleği, ekipçe sunulan hizmetin kalitesinin yolcular tarafından yüksek algılanabilmesi için uyum içerisinde çalışmayı gerektirmektedir. Ekip çalışması, ekip üyelerinin yardımlaşarak ve mesleki bilgilerini birbirleri ile paylaşarak ortak performans sergiledikleri bir faaliyettir. Bu nedenle, kabin ekibi arasındaki uyumu bozarak performanslarını etkileyebilecek çatışmaların belirli bir düzeyde tutulabilmesi havayolu 
açısından önem arz etmektedir.

Alanyazında kabin ekiplerini konu alan çatışma yönetimi çalışmaları incelendiğinde, genellikle kabin ekibi ile kokpit ekibi ve kabin ekibi ile yolcular arasında yaşanan çatışmalara yer verildiği görülmektedir. Kabin ekibi üyeleri arasında yaşanan çatışmaları tecrübeli ve sinyor kabin görevlileri kapsamında inceleyen çalışmaya ise rastlanmamıştır.

Her mesleğin kendine özgü dinamikleri bulunmaktadır. Kabin görevliliği mesleği de özellikle kıdem ve pozisyon söz konusu olduğunda çalışanlar arasında önemli statü ve yetki farklılıklarına neden olan kendine özgü bir dinamiğe sahiptir. Çoğu havayolunda, mesleğe bir gün ara ile başlayan iki kabin görevlisi arasında dahi ayrım bulunmaktadır. Bu ayrım o derece belirgindir ki uçağa ekipçe giriş çıkışlarda, yurtdışı uçuşu için pasaport işlemi sırası beklerken, iş ile ilgili bir evraka ekipçe imza atarken ya da yatı görevinde resepsiyon görevlisinden otel odasının anahtarı teslim alınırken kıdem sırasına göre hareket edilmesini gerektirmektedir. Bir kabin görevlisinin, bu kurallar çerçevesinde mesleki tecrübe edindikten sonra, diğer kabin görevlerinden çok daha keskin bir şekilde ayrılarak kabin ekibinin iş amacıyla birlikte olduğu her yerde ilk sırayı alması ve ekibindekiler üzerinde havayolunun talimat ve prosedürleri kapsamında tartışmasız bir otoriteye sahip olması ancak kabin amirliğine terfi ile gerçekleşmektedir.

Dışarıdan bakıldığında kabin görevliliğinden kabin amirliğine yalnızca bir adet kariyer basamağı çıkılarak ulaşıldığı görülmektedir. Ancak, bu şekilde işleyen bir çalışma ortamında kabin amirliği pozisyonunda görev yapmanın getirisi, birçok meslekte yalnızca bir basamak ilerlemenin getirisinden çok daha farklı olmaktadır. İşyerinde önemli derecede statü kazanılmakta ve uçakta kabin bölümün sorumlusu olarak yapılan işin fiziksel yükü kabin görevlilerinin fiziksel iş yüküne oranla büyük ölçüde azalmaktadır.

Birçok havayolu, ulusal ve uluslararası havacılık otoritelerince belirlenen kabin amiri olarak görevlendirilme kriterlerine kendi ilavelerini yapmaktadır. Genellikle havayolunda çalışılan süre, yabacı dil bilgisinin belirli bir seviyenin üzerinde olması, havayolunun verdiği eğitimlerde gösterilen performans, devamsızlık ve aksaklık sayıları gibi kriterleri karşılayabilen kişiler aday olarak seçilmektedir. Tecrübeli olmasına karşın diğer kriterleri karşılayamayan kabin görevlilerinin kabin amirliğine terfi hakkı bulamamaktadır. Kriterleri karşılayabilen kabin amiri adayları arasından mülakat aşamasını geçerek eğitime kabul edilenlerin, eğitim süresince gösterdikleri performans ve eğitim sonunda yapılan bitirme sınavındaki başarı durumları dikkate alınarak, kabin amirliği alıştırma ve kabin amirliği kontrol uçuşları yaptırılmaktadır. Uzun ve zorlu geçen kabin amirliğine terfi süreci, kriterleri karşılayan her kabin görevlisi tarafından başarıyla sonuçlandırılmamaktadır.

Kabin amirliği için gerekli tecrübeye sahip bir kabin görevlisinin diğer kriterleri karşılayamamasının ya da aday sürecini başarıyla tamamlayamamasının, yukarıda açıklanmaya çalışılan iş ortamının etkisiyle büyük bir motivasyon kaybına sebebiyet verebileceği çıkarımı yapılabilmektedir. 
Havayolu işletmeleri, benimsemiş oldukları rekabet stratejisine bağlı olarak farklı iş modelleri uygulayabilmektedir. Genel olarak tam hizmet sağlayıcı havayollarının kabin ekiplerine sunduğu ücret ve sosyal haklar, diğer havayolu iş modellerine göre daha iyi olmaktadır. Bu nedenle, çoğunlukla tam hizmet sağlayıcı havayolu dışındaki iş modellerinde çalışan ve belirli bir tecrübeye sahip olan kabin görevlileri ve hatta kabin amirleri, daha iyi ücret ve sosyal haklar elde edebilmek için tam hizmet sağlayıcı havayollarına transfer olabilmektedir. Aynı şekilde, yeterli tecrübeye sahip olmalarına karşın tam hizmet sağlayıcı havayolunun diğer kriterlerini karşılayamayan ya da aday sürecini başarıyla tamamlayamayan kabin görevlileri, diğer iş modellerinde belirlenen kabin amirliği kriterlerini karşlayabilmeleri durumunda nadiren de olsa transfer olabilmektedir. Dolayısıyla, daha iyi ücret ve sosyal haklar için kıdem ve pozisyonundan kendi isteğiyle vazgeçen bir kabin görevlisi ya da kabin amiriyle, gerekli kriterleri sağlayamadığ aday sürecinde başarılı olamadığı için kabin amirliğine terfi edemeyerek havayolunda çalışmaya devam eden bir kabin görevlisinin motivasyon düzeyi, tutum ve davranışları arasında belirgin bir farklılık olabileceği çıkarımında bulunulabilmektedir.

Tecrübeli ve sinyor kabin görevlilerinin sergiledikleri tutum ve davranışların kabin ekibi üyeleri arasında olumlu ya da olumsuz çeşitli etkilere neden olabileceğine ve çatışma yönetimi açısından araştırılması gerektiğine karar verilebilmesi için, öncelikle kabin görevliliği mesleğinin dinamikleri hakkında yukarıda açıklanmaya çalışılan bilgilere ulaşabilen ya da yeterli derecede kabin görevliliği tecrübesi bulunan bir araştırmacının olması gerektiği ve bu nedenle alanyazında, tecrübeli ve sinyor kabin ekipleri özelinde kabin ekibi üyeleri arasında çatışma yönetimine dair yapılan bir çalışmaya rastlanılamadığı düşünülmektedir.

Alana ve sektöre katkı sağlaması amacıyla yapılan bu araştırmanın sonucunda; kabin amirlerinin, kendilerinden yaşça büyük tecrübeli ve sinyor kabin görevlileri hakkında farklı duygu ve düşüncelere sahip oldukları ve çatışmaları yönetmek için farklı yöntemler tercih ettikleri bulgusuna ulaşılmıştır. Kabin amirleri genellikle, transfer yoluyla gelen tecrübeli kabin görevlileri için uzlaşmacı çatışma yönetimi yöntemini, havayolunda kabin amirliğine terfi edememiş sinyor kabin görevlileri için ise egemen olma çatışma yönetimi yöntemini tercih etmektedir.

Araştırmanın bulgularına dayandırılarak yapılan çıkarımlara göre, kabin amirlerinin, yaşça kendilerinden büyük ve daha tecrübeli kabin görevlilerine farklı davranışlarda bulunarak farklı çatışma yönetimi yöntemlerini tercih etmeleri, kabin görevlilerinin kişisel özelliklerinden ve motivasyon düzeylerinden kaynaklanmaktadır. Transfer yoluyla gelen kabin görevlileri çoğunlukla dışa dönük kişilik özellikleri sergileyen, yardımsever, paylaşımcı, eleştiriye açık ve uyumlu kişiler olarak görülmektedir. Havayolunun kabin amirliğine terfi edememiş tecrübeli kabin görevlileri ise çoğunlukla kabin amiri ile samimi ilişkiler kurmaktan uzak duran, mutsuz, çalışmaya isteksiz ve kabin amiri ile rekabet halinde olduğunu gösteren davranışlar sergileyen kişiler olarak görülmektedir.

Sonuç olarak kabin ekibinde, kabin amirinden yaşça büyük ve daha tecrübeli bir kabin 
görevlisi bulunması durumunda, kabin görevlisinin motivasyonuna ve kabin amiriyle olan etkileşimine göre çatışma yaşanma ihtimali değişmektedir. Genel olarak transfer yoluyla gelen tecrübeli kabin görevlileri ekibe yardımcı olarak hizmet kalitesinin artmasına katkı sağlarken, havayolunun kabin amirliğine terfi edememiş sinyor kabin görevlileri ekip uyumunun azalmasına ve dolayısıyla hizmet kalitesinin düşmesine etki edebilmektedir.

Çatışmanın belli bir oranda yaşanması, ekip motivasyonu ve performansı üzerinde olumlu etki yaratabilmektedir. Havayolları, çatışma düzeyini istenilen seviyede tutabilmek için sinyor kabin görevlilerinin kişisel ve mesleki eğitimlerine daha fazla ağırlık vermelidir. Yeterlilikleri artırılan sinyor kabin görevlilerinin amirlik pozisyonuna terfi ettirilmesi, çatışma düzeyinin istenilen düzeyde tutulmasına ve hizmet kalitesinin artırılmasına aracılık edebilecektir. Ekip oluşturma sürecinde, yüksek düzeyde çatışmaya neden olarak ekip uyumunu ve dolayısıyla hizmet kalitesini olumsuz etkileyebilecek yaş, tecrübe ve bu tecrübenin mevcut ya da farklı havayolunda kazanılmış olması gibi değişkenlerin dikkate alınması, kabin ekibi üyeleri arasındaki çatışma düzeyinin azalmasına ve böylece havayolunun karlılık ve sürdürülebilirliğine katkı sağlayabilecektir.

\section{SINIRLILIKLAR VE GELECEKTEKİ ARAŞTIRMALAR İÇIN ÖNERİLER}

Araştırma, Türkiye' de faaliyet gösteren bir havayolunda çalışan 10 kabin amirine, kasti örneklem seçim tekniğiyle ulaşılarak gerçekleştirilmiştir. Tecrübeli ve sinyor kabin görevlilerinin görüşlerinin de alınarak kabin amirlerinin görüşleriyle eşleştirilmemesi araştırmanın sınırlılığıdır.

Gelecekteki araştırmalarda görüşme yapılan kişi ve görev yapılan pozisyon sayının artırılması, bulgularımızın desteklenmesi ve olgunun derinlemesine anlaşılmasına destek olması bakımından tavsiye edilmektedir. Kabin görevlileri ve amirlerinin tutum ve davranışları ile benimsedikleri çatışma yönetimi yöntemlerinin kantitatif verilerle desteklenmesi, araştırmanın boyutunu genişletecektir. 


\section{KAYNAKÇA}

Akdil, A. ve Akpınar A.T. (2016). Classification Of Passenger Airlines in Turkey Based On Porter's Generic Strategies. Porter'in Jeneric Stratejilerine Dayalı Olarak Türkiyedeki Havayollarının Sinıflandırılması in IMDA 25. World Business Congress, Londra.

Akpınar, A. T. ve Erdağ, T. (2018). Sustainable Performance Assessment System Model Suggestion for Cabin Crew in Different Airlines. Osman Geyik, O., Gacar, A. (Ed.) in CUDES 2018 7, International Congress on Current Debates in Social Science Programme \& Abstract Book. İstanbul: Kayhan Printing Co Ltd.: 91.

Akyurt, İ. Z. ve Toplu Yaşlığlu, D. (2018), Havacılık Sektöründe Ekip Planlama Yönetimi: Bir Türk Havayolu Örneği, İşletme Araştırmaları Dergisi, 19 (1), 431.

Avram, B. (2017). The Hybrid Airline Model. Generating Quality for Passengers. Expert Journal of Business and Management, 5 (2), 149- 154.

Assael, H. (1990). Marketing: Principles and Strategy. Orlando: The Dryden Press.

Bacharach, S. B. ve Edward, J. L. (1981). Power and Tactics in Bargaining. Industrial and Labor Relations Review, 34 (2), 219.

Burchill, F. (1999). Walton and McKersie, A Behavioral Theory of Labor Negotiations (1965). Historical Studies in Industrial Relations, (8), 140.

Canöz, N. (2017). Türkiye’deki Havayolu İşletmelerinin Hizmet Anlayışlarının Belirlenmesine Yönelik Bir Araştırma. Selçuk Üniversitesi Sosyal Bilimler Meslek Yüksekokulu Dergisi, 20 (2), 194.

Creswell, J. W. (2007). Qualitative Inquiry and Research Design: Choosing Among Five Approaches Second Edition. California: Sage Publications, Inc.

Curtisa, S.; Geslerb, W.; Smitha, G. ve Washburnb, S. (2000). Approaches to Sampling and Case Selection in Qualitative Research: Examples in The Geography of Health, Social Science \& Medicine, (50), 1002.

Deutsch, M. ve Krauss, R. M. (1962). Studies of Interpersonal Bargaining. The Journal of Conflict Resolution, 6 (1), 53.

Erdağ, T. (2019). Performans Değerlendirmenin Hizmet Sektöründe Yeri ve Önemi: Artan Transfer Nedeniyle Farklı Havayollarında Kabin Görevlilerine Yönelik Sürdürülebilir Performans Değerlendirme Sistem Modeli Önerisi. Kocaeli Üniversitesi Sosyal Bilimler Enstitüsü, Kocaeli, s. 52.

Hartwick, J. ve Barki, H. (2004). Conceptualizing the Construct of Interpersonal Conflict. 
International Journal of Conflict Management, 15 (3), 5.

Jehn, K. A. ve Bendersky, C. (2003). Intragroup Conflict in Organizations: A Contingency Perspective on The Conflict- Outcome Relationship. Research in Organizational Behavior, 25, 188- 228.

Kasirzadeh, A.; Saddoune, M. ve Soumis, F. (2015). Airline Crew Scheduling: Models, Algorithms, and Data Sets, EURO I Transp Logist, s. 5.

Kim, Y. ve Park, H. (2014). An Investigation of the Competencies Required of Airline Cabin Crew Members: The Case of a Korean Airline. Journal of Human Resources in Hospitality \& Tourism, 13, 34-62

Koch, B. (2010). Aviation Strategy and Business Model, Wald, A., Fay, C., Gleich, R. (Ed.), Introduction to Aviation Management, Berlin: LIT Verlag, 154.

Küçükönal, H. ve Korul, V. (2012), Havayolu İşletmelerinde İnsan Kaynakları Yönetimi, Sosyal Bilimler Dergisi, (24), 89.

Ku, E. C. S.; Chen, F. ve Wei, K. (2014), Transition Process Activities and Team Efficacy of Flight Attendants, Journal of Air Transport Management, (40), 119.

Lewicki, R. J. (1997). 'Teaching Negotiation and Dispute Resolution in Colleges of Business: The State of the Practice'. Negotiation Journal, 253- 265.

Mack, R. W. ve Snyder, R. C. (1957). 'The Analysis Of Social Conflict- Toward an Overview and Synthesis. Conflict Resolution, 1 (2), 218.

Mathersi, N.; Fox, N. ve Hunn, A. (1998). Trent Focus for Research and Development in Primary Health Care: Using Interviews in a Research Project, Trent Focus, 4.

Mitropoulos, P. ve Memarian, B. (2012), Team Processes and Safety of Workers: Cognitive, Affective and Behavioral Processes of Construction Crews, Journal of Construction Engineering and Management, 138 (10), 1182.

Monfries, M. M. ve Moore, P. J. (1999). Interpersonal Skills in Aviation: Applications and Development Interpersonal Skills in Aviation: Applications and Development, JAAER, 9 (1), 26.

Okçu, V.; Doğan, E. ve Dayanan, İ. (2018). Öğretmenlerin Okul Kültürü Algılarının Okul Yöneticilerinin Çatışma Yönetimi Stilleri Üzerindeki Etkisi (Şırnak İli Örneği), Anadolu Ĕ̈itim Liderliği ve Öğretim Dergisi, 6 (2), 42.

Özdemir, M. (2010). Nitel Veri Analizi: Sosyal Bilimlerde Yöntembilim Sorunsalı Üzerine Bir Çalışma, Eskişehir Osmangazi Üniversitesi Sosyal Bilimler Dergisi, 11 (1), 332. 
Özdemir, U. (1999), Psikiyatri Tedavi Ekibinin Ekip Çalışması Kavramına İlişkin Kendi Bilgilerini ve Çalıştıkları Psikiyatri Tedavi Kurumlarını Değerlendirmeleri, Kriz Dergisi, 7 (2), 17-24.

Patton, M. Q. (2014). Nitel Araştırmanın Doğası, Bütün, M., Demir, S. B. (Ed.), Nitel Araştırma ve Değerlendirme Yöntemleri 3. baskı, Ankara: Pegem Akademi, 4.

Peratanasumran, S. ve Sitthichoke, S. (2015). A Study of Conflict Management in an Airline Industry: An Intercultural Approach, 18- 25.

Pondy, L. R. (1967). Organizational Conflict: Concepts and Models. Administrative Science Quarterly, 12 (2), 296.

Rubin, J. Z.; Pruitt, D. G. ve Kim, S. H. (1994). Mcgraw-Hill Series in Social Psychology. Social Conflict: Escalation, Stalemate, and Settlement 2. Baskl, New York, Mcgraw-Hill Book Company.

Sargut, S. (2015). Lider Yöneticinin Benliğine Yolculuk, İstanbul, Beta Yayınları.

Schmidt, S. M. ve Kochan, T. A. (1972). Conflict: Toward Conceptual Clarity. Administrative Science Quarterly, 17 (3), 359.

Shaw, S. (2007). Airline Marketing and Management, Burlington, Ashgate Publishing Company.

SHGM, Sht - Kabin Yol Boyu (Kabin Yol Boyu Denetimlerine İlişkin Esas ve Usuller Talimatı), 1.

Shammugam, S. ve Marimuthu, M. (2019), Does Conflict of Top Management Team Impact the Firm Performance? A Conceptual Review on Large Companies in Malaysia, Global Business and Management Research: An International Journal, 11 (2), 158.

SHGM, Kabin Memuru, http://web.shgm.gov.tr/tr/havacilik-personeli/2138-kabinmemuru (Erişim tarihi: 4 Aralık 2019).

Şekerli, E. B. ve Gerede, E. (2011). Sub Cultural Differences Among Turkish Air Transport Pilots in Terms Of Crew Resource Management- Specific Non- Technical Skills, Atatürk Üniversitesi İktisadi ve İdari Bilimler Dergisi, 25 (2), 28.

Tekin, H. H. (2006). Nitel Araştırma Yönteminin Bir Veri Toplama Tekniği Olarak Derinlemesine Görüşme, İstanbul Üniversitesi Sosyoloji Dergisi, 3 (13), 101.

THK Üniversitesi, Sivil Havacılık Kabin Hizmetleri Programı, https://ihmyo.thk.edu.tr/ wp-content/uploads/sites/20/2019/07/Sivil-Havac1lık-Kabin-Hizmetleri-Tanıtım- 
Sunumu.pdf/ (Erişim tarihi: 10 Aralık 2019).

Tjosvold, D. (2006). Defining Conflict and Making Choices About Its Management. Lighting The Dark Side of Organizational Life, IJCMA, 17 (2), 89-90.

Tümüklü, A. (2000). Eğitim Bilimi Araştırmalarında Etkin Olarak Kullanılabilecek Nitel Bir Araştırma Tekniği: Görüşme, Kuram ve Uygulamada Eğitim Yönetimi, (24), 547.

Yazgan A. E. ve Yiğit, S. (2013). Türk Sivil Havacılık Sektörünün Uluslararası Rekabetçilik Düzeyinin Analizi, Selçuk Üniversitesi İIBF Sosyal ve Ekonomik Araştırmalar Dergisi, (25), $421-445$.

Yıldız, O. ve Erdil, S. (2013). Türkiye Havayolu Yolcu Taşımacılığı Sektöründe Hizmet Kalitesinin Karşılaştırmalı Ölçümlenmesi, Öneri Dergisi, 10 (10), 89.

\section{EK- 1: Yarı yapılandırılmış görüşme tekniğine uygun olarak çalışmada kullanılmak üzere hazırlanmış sorular:}

-Yaşınız?

•Bu havayolunda kaç yıldır kabin görevlisi olarak çalışmaktasınız?

-Daha önce kabin görevlisi olarak başka bir havayolunda çalıştınız mı?

- Halen çalışmakta olduğunuz havayolunda kaç yıldır kabin amiri olarak görev yapiyorsunuz?

-Görev yaptığınız uçuşlarda sizden daha tecrübeli kabin görevlileri ile karşılaşıyor musunuz?

-Tecrübesi sizden fazla olan kabin görevlileri yaş olarak da sizden büyük mü?

-Karşılaştığınız kabin görevlileri genellikle sizden kaç yaş büyük ve kaç yıl daha tecrübeli oluyorlar?

-Tecrübesi sizden fazla olan kabin görevlileri başka havayollarından transfer edilen kişilerden mi oluşuyor?

- Tecrübesi sizden fazla olan kabin görevlileri arasında şu anki havayolunda sizden daha eski birer çalışan olmalarına karşın kabin amirliğine terfi ettirilmemiş kişilerle birlikte görev yaptı̆̆ınız oluyor mu?

•Ekibinizdeki sizden daha tecrübeli ve yaşça büyük kabin görevlileri ile iletişiminiz, 
ekipteki diğer kabin görevlileriyle olan iletişiminizle aynı mı?

-Tecrübe ve yaş olarak sizden büyük kabin görevlilerinin, sizinle ve diğer kabin görevlileriyle iletişimi, diğer kabin görevlilerinin sizinle ve kendi aralarındaki iletişimleri ile aynı şekilde mi gerçekleşiyor?

-Ekibinizde sizden daha tecrübeli ve yaşça büyük bir kabin görevlisi olmasının, aranızda problem yaşanmasına neden olacak düzeyde, sizin ve diğer kabin görevlilerinin üzerinde gerginliğe neden olduğunu düşünüyor musunuz?

-Ekibinizde sizden yaşça büyük ve tecrübeli kabin görevlisi olması durumunda yaşadığınız problemler nelerdir?

-Ekip üzerindeki hakimiyetinizi devam ettirebilmek için diğer uçuşlarınıza göre daha farklı davranışlar sergiliyor musunuz?

-Ekibinizdeki tecrübeli ve yaşça büyük kabin görevlisinin, hatalı ya da takdir gerektiren davranışlarını kendisine bildiriyor musunuz? Bilgilendirme yaparken kendinizi rahat hissediyor musunuz?

-Ekibinizde sizinle ya da ekip arkadaşlarıyla arasında anlaşmazlık bulunan tecrübeli ve yaşça büyük bir kabin görevlisi varsa uçuşun sorunsuz devam etmesini sağlamak için ne tür önlemler alıyorsunuz?

-Uçuş görevinde sizden yaşça büyük bir ekip üyesiyle liderliğiniz konusunda mücadele etmeyi uygun bulur musunuz? Uygun görüyorsanız, liderin kim olduğunu gösterme çabasına giriyor musunuz? Uygun görmüyorsanız, o uçuş görevi boyunca tecrübeli ve yaşça büyük kabin görevlisini idare ederek tartışmayı uzatmamayı mı seçiyorsunuz?

-Ekipte yaşça büyük ve tecrübeli bir kabin görevlisi ile sorun yaşarsanız, diyalog kurarak sorunu çözebiliyor musunuz?

-Tecrübeli kabin görevlisi olarak transfer edilen kabin görevlileriyle mi yoksa sizinle aynı havayolunda sizden daha önce işe başlamış ancak kabin amirliğine terfi ettirilmemiş kabin görevlileriyle mi görev yapmayı tercih edersiniz? 
EK- 2: Araştırmaya katılan kabin amirlerine ilişkin bilgiler

\begin{tabular}{|l|l|l|}
\hline \multirow{2}{*}{ Cinsiyet } & Değişkenler & $\mathbf{f}=$ frekans \\
\hline \multirow{3}{*}{ Yaş } & Erkek & 4 \\
\cline { 2 - 3 } & Kadın & 6 \\
\hline \multirow{3}{*}{ Kabin Amir Görevindeki Tecrübe } & $28-35$ yaş & 6 \\
\cline { 2 - 3 } & $35-40$ yaş & 4 \\
\hline \multirow{5}{*}{ Kabin Görevlisi Olarak Toplam Tecrübe } & $3-5$ yıl & 2 \\
\cline { 2 - 3 } & $6-8$ yıl & 6 \\
\cline { 2 - 3 } & $9-12$ yıl & 1 \\
\cline { 2 - 3 } & $5-7$ yıl & 2 \\
\cline { 2 - 3 } & $8-10$ yıl & 6 \\
\hline \multirow{2}{*}{ Çalışılan Havayolu Sayısı } & $11-15$ yıl & 1 \\
\hline & 1 Havayolu & 10 \\
\cline { 2 - 3 } & 2 veya daha fazla & - \\
\hline
\end{tabular}

